\title{
The Advances in Understanding Erodibility of Soils in Unpaved Roads
}

\author{
Esdras Ngezahayo', Michael P.N. Burrow ${ }^{2}$, Gurmel S. Ghataora ${ }^{2}$ \\ 1Department of Civil Engineering, School of Engineering, University of Birmingham \\ Edgbaston, B15 2TT, Birmingham, United Kingdom \\ EXN396@bham.ac.uk \\ ${ }^{2}$ School of Engineering, University of Birmingham \\ Edgbaston, B15 2TT, Birmingham, United Kingdom \\ m.p.n.burrow@bham.ac.uk; g.s.ghataora@bham.ac.uk
}

\begin{abstract}
More than 90\% of the road network in rural areas of the developing countries is unpaved and comprises of either gravel or earth roads. Such roads are prone to erosion leading to the formation of potholes, rills and gullies. Many studies have been undertaken on soil erosion, but only a few are focussed on earth roads. A systematic analysis of research on erosion of soils in earth roads was undertaken to draw out lessons that can be learnt. 564 studies were assessed. Of these only 85 were relevant to earth roads. Most significant erosion driver was total rain, rainfall duration and intensity. Further findings were that the key factors that affected soil erosion in earth roads were soil type, clay content, soil plasticity, and particle size distribution; degree of the surface layer compaction, and traffic loading and speed. To challenge and validate the findings of the literature, the main factors affecting erosion were controlled during laboratory erodibility tests of a sand soil mixed with its 0\%, 5\%, $10 \%, 15 \%$ and $20 \%$ china clay and of a granular subbase material. The soils were compacted at their maximum dry densities and subjected to a simulated rainfall intensity of $30 \mathrm{~mm} / \mathrm{hr}$ for 30 minutes, and at $0 \%$ and $6 \%$ slopes. Interestingly, laboratory results agreed with the literature. Erodibility increased with increase in rainfall duration and slope gradient. In sand - china clay mixes, erodibility reduced with increased clay content. An increment of 5\% china clay corresponded to a reduction of eroded sediment of about $8 \%$ to $12 \%$. The subbase soil material was very less erodible due to its robust particle size that resisted detachment due to rain drops. Moreover, it was observed that most soils were detached and eroded within the first 15 minutes of the rainfall after which detachment reduces.
\end{abstract}

Keywords: Unsurfaced roads, erosion, erodibility, erosion factors, erosion rate.

\section{Introduction}

About $80 \%$ of world roads are unpaved [1] and it could be more than $90 \%$ in rural areas of the developing countries [2]. Those are both gravel and earth roads. The latter are based on compacted natural soils forming the surface layer which accommodates traffic runs. Gravel roads on the other hand may have additional layer of borrowed granular material which is compacted to form the surface layer. Rural roads help rural social and economic growth. Despite this, they attract little investments in engineering and maintenance. As result, they are usable in dry season though with unwanted dust, and become muddy, slippery, with rills, gullies and potholes in rainy season. Only $37 \%$ of people in rural areas of developing countries have access to all-weather road within $2 \mathrm{~km}$ compared to $94 \%$ in developed countries [1], [3]. Sub-Saharan Africa (SSA) is the most vulnerable region with heavier burden on rural women and children [4]. A systematic investigation on erodibility of soils in earth roads was undertaken, key erosion types (Table 2) and factors affecting erodibility (Figures 4 and 5) discussed. Envelopes for soil erodibility trends due to both raindrop energy and subsequent flow velocity (Figure 7) have been given to shed light on necessary measures for combating erosion in those roads that are vital for developing countries. Moreover, the laboratory testing of sandy soil mixed with its $0 \%, 5 \%, 10 \%, 15 \%$ and $20 \%$, and testing of a granular subbase material have been conducted with results confirming the findings of the literature. 


\section{The global meaning of earth roads}

The poor condition of rural roads negatively affect the development due to their impact to the social, economic and development factors which hugely depend on the movement of people and goods. For example, Tanzania (TZ) in 1988 lost $50 \%$ of cotton harvest in three regions, $80 \%$ of rice paddy in one region and more than $50 \%$ of seeds and fertilizers in another region due to poor rural transport [4]. Currently, $10 \%$ to $40 \%$ of TZ's agricultural harvest cannot be moved to desired markets and Cook et al. [5] attribute 89\% of the problem to poor rural roads condition. Table 1 gives percentages of earth roads in selected countries to highlight their importance. Percentages of unpaved roads in the world, in SSA, and in countries such as Brazil, Canada and USA show that the good condition of those roads is imperative for the wellbeing of several communities.

Table 1: Unpaved roads in the world, SSA and eight selected countries with long road networks.

\begin{tabular}{|c|c|c|c|c|c|c|}
\hline & \multicolumn{4}{|c|}{$[3]$} & \multirow{2}{*}{\multicolumn{2}{|c|}{$\begin{array}{l}{[6]} \\
2017\end{array}$}} \\
\hline & \multicolumn{2}{|l|}{1998} & \multicolumn{2}{|l|}{2008} & & \\
\hline & Length $\left(* 10^{6} \mathrm{~km}\right)$ & Unpaved (\%) & Length $\left(* 10^{6} \mathrm{~km}\right)$ & Unpaved (\%) & Length $\left(* 10^{6} \mathrm{~km}\right)$ & Unpaved (\%) \\
\hline World & 29.912 & 49.2 & 33.839 & 42.6 & 64.285 & $\geq 70$ \\
\hline USA & 6.310 & 41.0 & 6.494 & 32.6 & 6.586 & 34.6 \\
\hline China & 2.210 & 82.0 & 3.730 & 46.5 & 4.577 & 11.6 \\
\hline India & 3.010 & 51.0 & 3.320 & 48.0 & 4.699 & 39.0 \\
\hline Brazil & 1.630 & 90.4 & 1.633 & 87.1 & 1.580 & 86.5 \\
\hline Japan & 1.152 & 25.1 & 1.204 & 20.2 & 1.218 & 18.5 \\
\hline Canada & 0.902 & 64.7 & 1.042 & 60.1 & 1.042 & 60.1 \\
\hline France & 0.893 & 0.0 & 1.027 & 0.0 & 1.028 & 0.0 \\
\hline Russia & 0.948 & 22.8 & 0.982 & 21.0 & 1.283 & 27.7 \\
\hline SSA & 1.837 & 86.9 & 2.296 & 84.8 & 2.380 & 80.6 \\
\hline
\end{tabular}

\section{A permanent threat to earth roads}

The integrity of unpaved roads depends on factors which together resist natural and functional stresses. Usually earth roads are made of locally selected soils which may have to be stabilized to gain engineering properties for construction. They need to be built and maintained in accordance with suitable standards and procedures. Those roads can fail due to lack of bearing capacity, overloading and surface erosion. The latter is manifested in formation of potholes, rills and gullies which if not addressed can make the road impassable. This study grouped 564 erosion studies into six categories as shown in Figure 1. Only about $15 \%$ of these related to unpaved roads. Further, 71 studies on surface erosion relevant to earth roads were detailed (Figure 2). $34 \%$ and $33 \%$ of those focused on sheet and rill erosion respectively while the remainder covered splash and gully erosions.

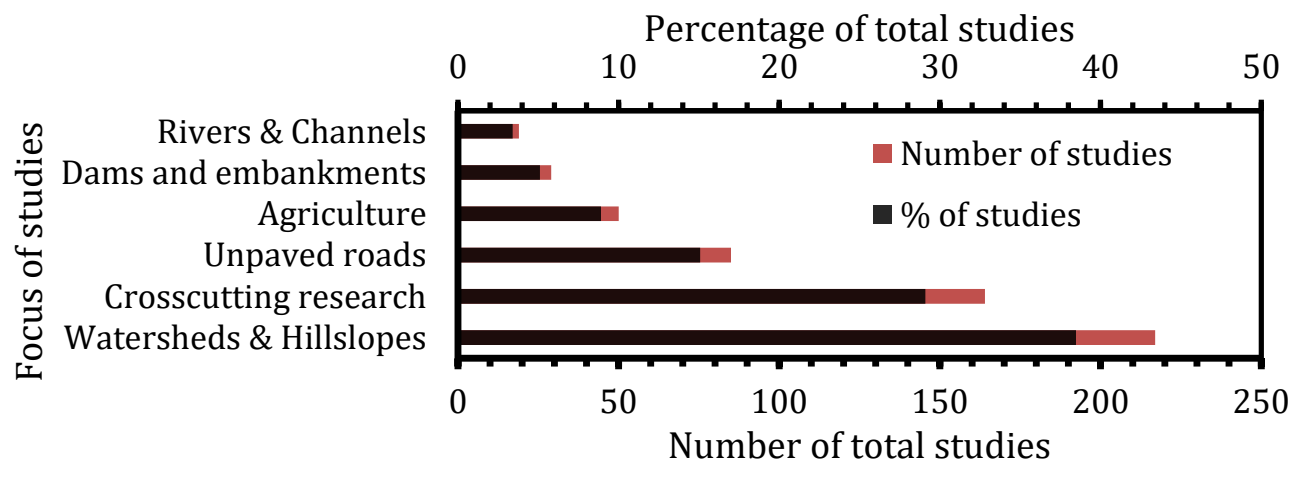

Figure 1. Erosion studies in different research focuses. 


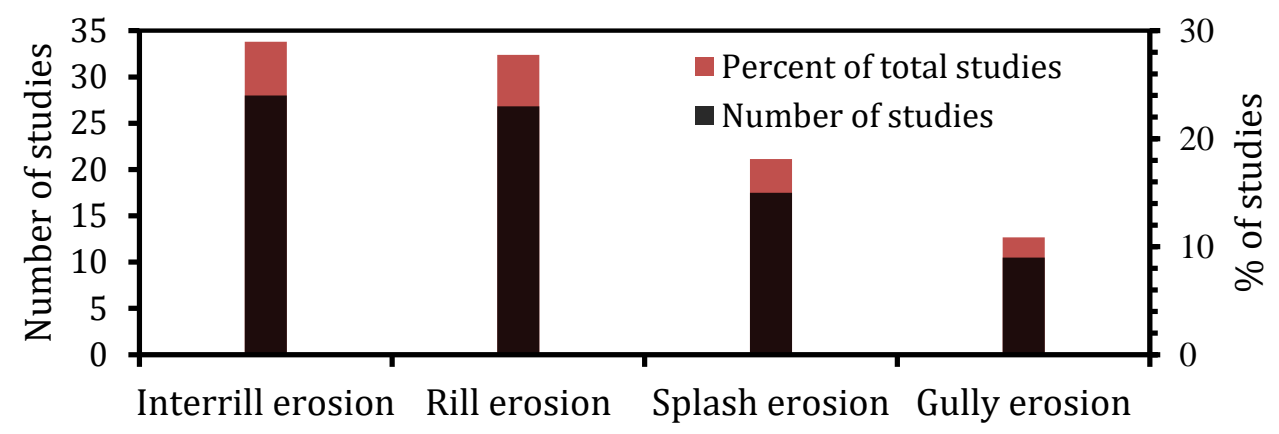

Figure 2. Water erosion types studies in unpaved rural roads.

\subsection{Splash erosion}

Known as rainfall erosion [7], [8], rain impact and rain induced erosion [9], splash is the starting point of surface water erosion [10]. Soil particles are detached by the raindrops impact kinetic energy (KE) [11]. This KE is absorbed by deforming, wetting, dislodging and upward reactive forces [12], [13], [14]. The reactive force entrains and moves particles but reduces due to its sensitivity to wind, soil type and soil water functions [12]. Detachment processes differ between bare and vegetated slopes with the latter dictated by plant canopy, leaf interception and raindrop size [15] while roughness, density and humidity are key for bare slopes. Therefore, earth roads are erosion detachment limited but covered slopes are transport limited [16].

\subsection{Sheet (inter-rill) erosion}

Inter-rill erosion occurs if there is enough rain to create surface flow. It is often combined with splash [17] because both are rain detachment affected [18]. However, there is a time gap between splash detachment [19] and overland flow start since thresholds for flow must be met. Sheet erosion affects topmost surface soils [17] with flow stresses detaching loose soils and moving these downslopes. Sheet detachment depends more on rain $\mathrm{KE}$ [20] and less on water flow stresses [21].

\subsection{Rill erosion}

Rill erosion results from sheet flow concentrating into small streams. Rills are narrow and shallow [22], [23] and increase in size as both traffic and rains increase. Rill and sheet erosions differ by detachment and transport processes. The rill erodibility depends on concentrated shear stresses [12] that become greater than critical stresses to detach soil particles. Most sediment on bare slopes is generated by rill erosion [18]. Entrainment and deposition refer to the mass of detached soils and disposed respectively. The net detachment is the activity of excess hydraulic stresses to critical stresses [24]. Also, net sediment deposition is the difference between deposition and entrainment when the former is greater, and the opposite way gives net erosion. Although unlikely, erosion equilibrium happens when entrainment and deposition equate [25].

\subsection{Gully erosion}

It is an advanced concentrated erosion. Gullies are wide and deep usually with tension cracks and cliffs [22]. These may form if rills are not treated [26] and can destroy the road [27]. [28] describe extreme gullies in Nigeria measuring up to $150 \mathrm{~m}$ in depth, $0.4 \mathrm{~m}$ to $5.6 \mathrm{~km}$ wide and up to $2.5 \mathrm{~km}$ long. [29] subdivide erosion types on slopes such as earth roads (Figure 3).

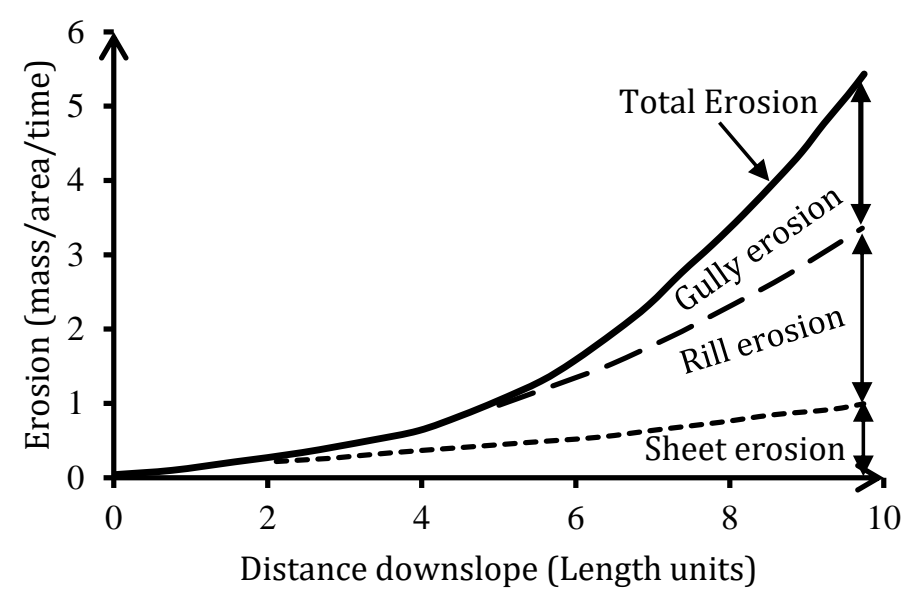

Figure 3. Contributions of erosion types on a slope (After [29]). 
Table 2. Water erosion and erosive forces.

\begin{tabular}{|l|l|l|}
\hline Type & Sub-type & Key erosive forces \\
\hline $\begin{array}{l}\text { Water } \\
\text { Erosion }\end{array}$ & $\begin{array}{l}\text { Splash } \\
\text { erosion }\end{array}$ & Rainfall kinetic energy [9] \\
\cline { 2 - 3 } & $\begin{array}{l}\text { Sheet } \\
\text { erosion }\end{array}$ & $\begin{array}{l}\text { Rainfall kinetic energy and } \\
\text { flow shear stresses [30] }\end{array}$ \\
\cline { 2 - 3 } & $\begin{array}{l}\text { Rill } \\
\text { erosion }\end{array}$ & $\begin{array}{l}\text { Concentrated flow shear } \\
\text { stresses [24] }\end{array}$ \\
\cline { 2 - 3 } & $\begin{array}{l}\text { Gully } \\
\text { erosion }\end{array}$ & $\begin{array}{l}\text { Concentrated flow shear } \\
\text { stresses [17] }\end{array}$ \\
\hline
\end{tabular}

\section{Interactive factors affecting erosion in earth road}

A study underway at the University of Birmingham has identified more than 2200 studies of soil erosion. These were systematically screened and narrowed to 564 good studies from which 99873 data were analysed in detail. The screening process based on the meaningful titles and abstracts at first; then on the methodology and results of studies. Inclusion and exclusion criteria that allowed to retain only studies that dealt with laboratory and field-based investigations on erosion processes and measurements were used. In this way, 219 studies were deliberately put aside for further analysis that helped to identify key factors affecting erodibility of soils in earth roads. Those can be grouped into environment and climate; geology and geotechnical; and road and traffic factors as it is shown in the Figure 4.
Environment and Climate factors: Precipitations, rain intensity, rain duration, raindrop size, raindrop shape, raindrop falling velocity, rain surface striking angle, weathering, flow stresses, water chemistry, freeze-thaw, humidity, wetting and dry cycles, slope properties and vegetation.
Road and Traffic factors: Road cuts and fills, longitudinal drainage systems, cross-drainage systems, traffic volume and type, traffic speeds, traffic frequency, road geometry, road size, road drainage area, road surface roughness, and maintenance regimes.

Geology and Geotechnical factors: Soil type, clay content, particle size distribution, shear strength, cohesion, bulk density, moisture content, maximum dry density, optimum moisture content, salts content, organic content, CBR, UCS, frication angle, consistency limits, aggregate stability, permeability, infiltration rate and infiltration capacity.

Figure 4. Classification of main factors affecting erosion in unpaved roads.

\subsection{Geology and Geotechnical factors}

Figure 5 shows that geology and soil lead the understanding of erosion. $82 \%, 32 \%$ and $31 \%$ of studies respectively relate particle size distribution, clay percent and index properties to erodibility. 26\%, 24\%, 23\%, 22\% and $21 \%$ of studies argued that shear strength, bulk density, organic content and compaction respectively influence erodibility in earth roads. Also, infiltration, permeability, particle stability, salts content, mineralogy and consolidation were reported to influence erosion.

Tests on loamy sand, silt loam and clay loam [31], loess [20], mixes of kaolin and sand, and kaolin, silt and sand [32] and consolidated sandy loam [33] showed that erodibility decreases as clay content and plasticity index (PI) [34] increase. [12] states that there is no single soil property that either does not impact soil erosion or that can alone be used to predict erodibility. [35], [36], [37], [38] argue that silt and fine sand erode more than gravel and clay soils due to weight and cohesion respectively. The soil shear strength that resists erosion stress decreases with increasing moisture [39], leading to formation of ruts and rills [40]. Figure 6 relates erosion rate $\left(E_{r}\right)$ and shear stresses $(\tau)$ to PI as recorded during erosion tests on 11 soils. It shows that $E_{r}$ decreases with increase in PI whilst $\tau$ increase with PI, though relations are a bit tenuous due to limited data. 


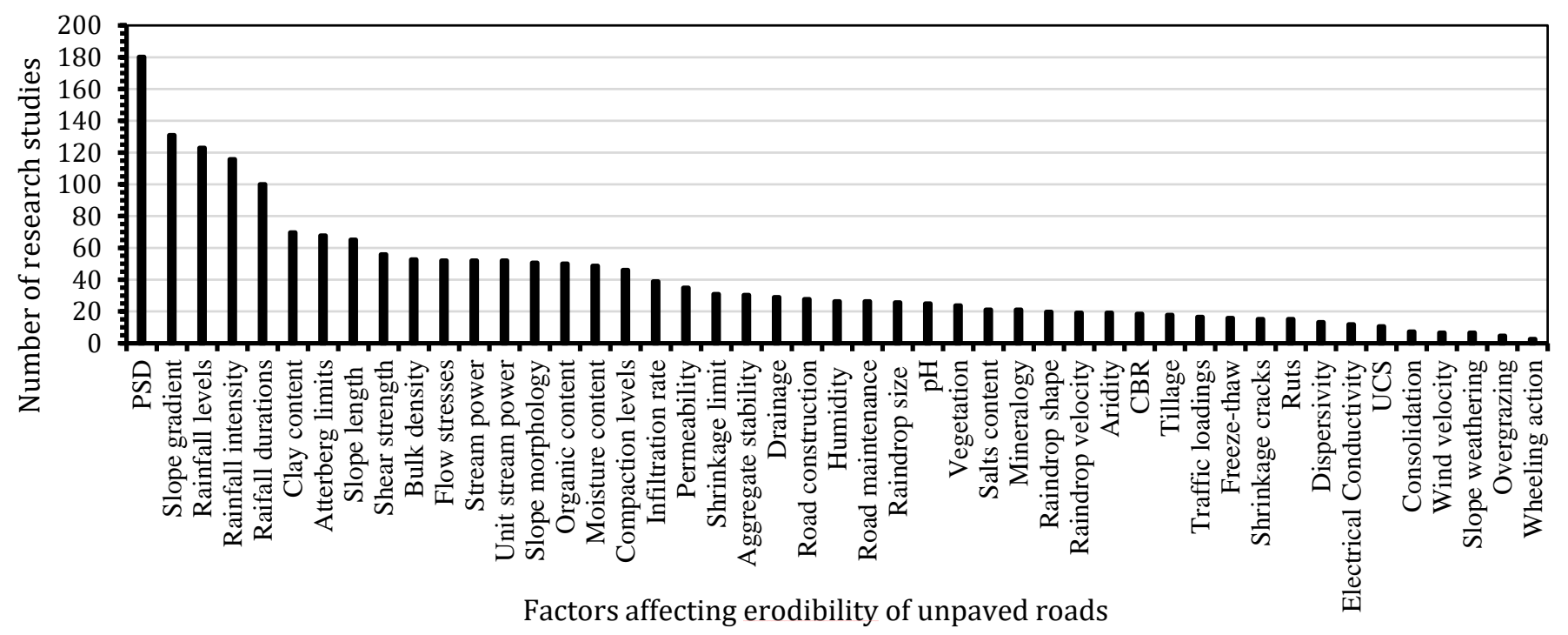

Figure 5. Erosion factors and number of consulted research studies.
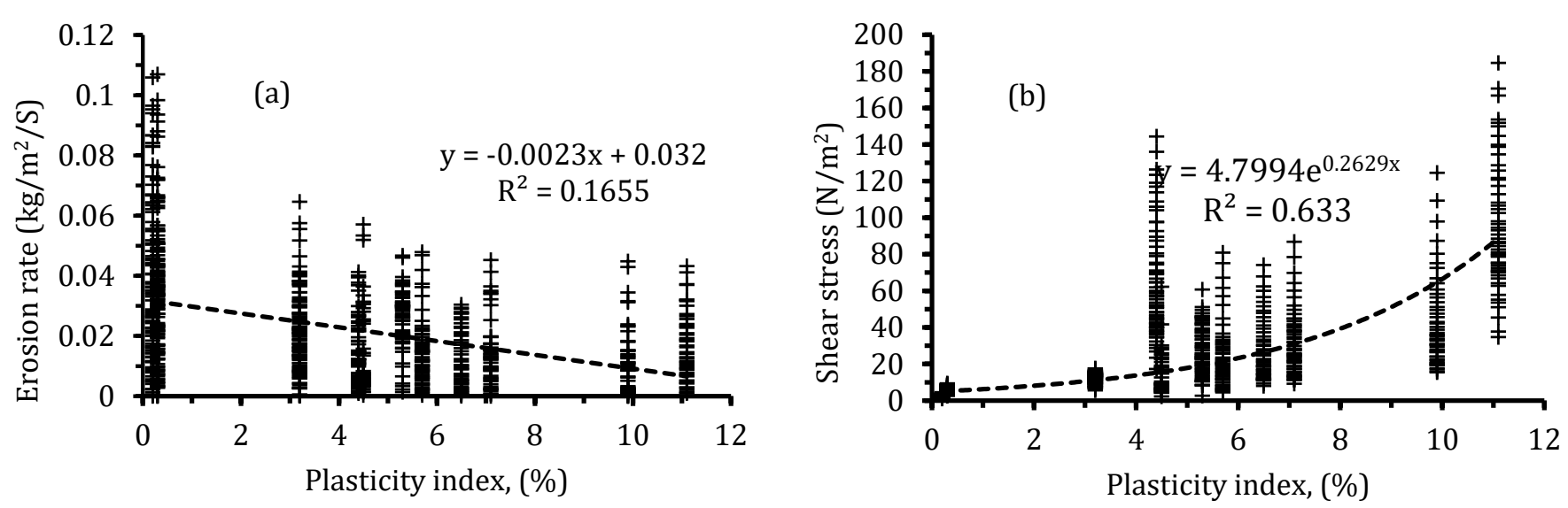

Figure 6. Erosion rate versus plasticity index (a) and shear stress versus plasticity index (b).

\subsection{Environment and Climate factors}

Environment and climate erosion factors include rain, rain intensity and duration, raindrop size, raindrop shape, rain falling height, weathering, flow stresses, water chemistry, freeze-thaw, humidity, wet - dry cycles and slope properties. Rain, its intensity and duration are with more effects on soil erodibility with $56 \%, 53 \%$ and $46 \%$ of studies respectively (Figure 5). Flow shear stresses and stream power were reported in $24 \%$ of studies each while $23 \%$ and $12 \%$ of studies argued impact of road position within a slope to erosion. Heavy rains increased erosion on silt loam and clay loam soils [41], [7] and on sandy loam and loam soils [41]. More erosion was reported due to high rain intensity [42], [43] and duration [44], [45], [46]. Usually, rain detaching energy depends on drops size, shape and velocity, wind and drop surface striking angle [47]. Salles et al. [19] studied erosivity in terms of raindrops size and velocity, and particle detachment energy on fine sand and silt loam. The study shows that energy decreases from clay to silts and then increases with particle size. Figure 7 gives an envelope for KE thresholds for splash detachment with respect to soil mean particle size $\left(D_{50}\right)$ and another one for sheet erosion critical velocity versus soil particle size. Also, splash, sheet and rill erosions increase with stream and unit stream powers [35], [48], [49], [50], [51]. 


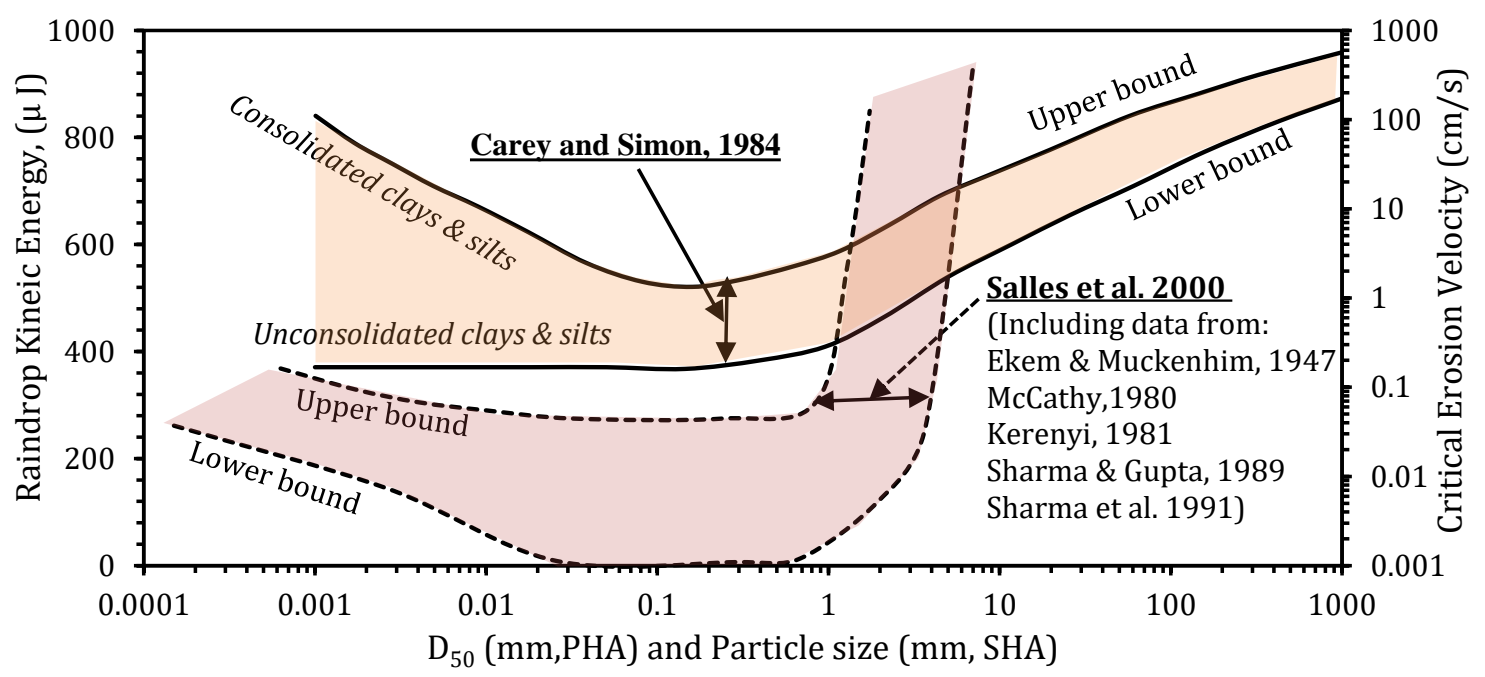

Figure 7. Rain energy versus mean particle size and flow critical velocity versus particle size.

Table 3. Factors and erosion trends in unsurfaced roads.

\begin{tabular}{|c|c|c|c|c|c|}
\hline \multirow[t]{2}{*}{ Factor (studies) } & \multicolumn{2}{|l|}{$\mathbf{F}$} & \multicolumn{2}{|l|}{$\mathbf{E}$} & \multirow[t]{2}{*}{ Comments and example references } \\
\hline & $\mathbf{I}$ & D & $\mathbf{I}$ & $\mathbf{D}$ & \\
\hline Clay \% (233) & $\sqrt{ }$ & - & - & $\sqrt{ }$ & \multirow{2}{*}{$\begin{array}{l}\text { The more the clay } \% \text {, the higher the cohesion and PI of soils. The } 3 \\
\text { parameters increase critical shear stresses [34] and reduce erosion }\end{array}$} \\
\hline Cohesion (99), PI (93) & $\sqrt{ }$ & - & - & $\sqrt{ }$ & \\
\hline Consolidation (30) & $\sqrt{ }$ & - & - & $\sqrt{ }$ & Consolidation strengthens soils and reduces erosion [33] \\
\hline Particle size (276) & $\sqrt{ }$ & - & $\sqrt{ }$ & - & Erosion reduces with particle size increase [19] \\
\hline Water content (148) & $\sqrt{ }$ & - & $\sqrt{ }$ & - & Shear strength lowers, soil loss increases [39], [54] \\
\hline Shear Strength (115) & $\sqrt{ }$ & - & - & $\sqrt{ }$ & Increase in critical shear stress [55] \\
\hline Bulk Density (142) & $\sqrt{ }$ & - & - & $\sqrt{ }$ & Increase in critical shear stress [37] \\
\hline Compaction (156) & $\sqrt{ }$ & - & - & $\sqrt{ }$ & Less erosion at maximum dry density [56] \\
\hline Salts content (53) & $\sqrt{ }$ & - & - & $\sqrt{ }$ & Salts in water increase resistance for clays [57] \\
\hline $\mathrm{pH}(68)$ & $\sqrt{ }$ & - & $\sqrt{ }$ & - & Higher $\mathrm{pH}$ values imply higher erosion susceptibility [57] \\
\hline Particle Stability (35) & $\sqrt{ }$ & - & - & $\sqrt{ }$ & Stable particles resist splash + water stresses [7] \\
\hline Organic content (76) & $\sqrt{ }$ & - & - & $\sqrt{ }$ & Organic $\%$ and wetting events enhance aggregate stability [58] \\
\hline Friction Angle (115) & - & $\sqrt{ }$ & $\sqrt{ }$ & - & The smaller the angle, the higher the soil detachment [59] \\
\hline Shear Stress (107) & $\sqrt{ }$ & - & $\sqrt{ }$ & - & More stresses dislodge more particles [20], [46] \\
\hline CBR (108), UCS (75) & $\sqrt{ }$ & - & - & $\sqrt{ }$ & Increase bearing capacity, strength and critical shear stress [60] \\
\hline Infiltration (78) & $\sqrt{ }$ & - & - & $\sqrt{ }$ & Particles $<0.125 \mathrm{~mm}$ improve cohesion $[61]$ \\
\hline Surface roughness $(8)$ & $\sqrt{ }$ & - & - & $\sqrt{ }$ & Reduces flow velocity and stresses [12] \\
\hline Gradient (262) & $\sqrt{ }$ & - & - & $\sqrt{ }$ & Steeper gradients produce more erosion [62] \\
\hline Road Grading (7) & $\sqrt{ }$ & - & $\sqrt{ }$ & - & Avail more soil for entrainment [62] \\
\hline Kinetic Energy (32) & $\sqrt{ }$ & - & $\sqrt{ }$ & - & Higher rain KE detaches more soil particles [19] \\
\hline Slope Patterns (137) & $\sqrt{ }$ & - & $\sqrt{ }$ & - & More concave, solar struck slopes showed higher erosion [63] \\
\hline Desiccation (34) & $\sqrt{ }$ & - & $\sqrt{ }$ & - & Decrease in soil strength [64] \\
\hline Thaw-Freeze (40) & $\sqrt{ }$ & - & $\sqrt{ }$ & - & Weakens soils, increases erosion [65], [66] \\
\hline Dispersion (25) & $\sqrt{ }$ & - & $\sqrt{ }$ & - & $>15 \%$ exchangeable salts, $\mathrm{pH}>7.8$, high dispersive \& erosion [67] \\
\hline Conductivity (27) & $\sqrt{ }$ & - & $\sqrt{ }$ & - & EC $>250 \mu \mathrm{s} / \mathrm{cm}$, sodium adsorption ratio $>10:$ dispersivity, + erosion [67] \\
\hline Rain features (273) & $\sqrt{ }$ & - & $\sqrt{ }$ & - & High rain amount, intensity and duration cause high erosion [41] \\
\hline Stream Power (107) & $\sqrt{ }$ & - & $\sqrt{ }$ & - & Stream power increases rill erosion [35], [49] \\
\hline Traffic effects (22) & $\sqrt{ }$ & - & $\sqrt{ }$ & - & Loosens soils for entrainment, creates rills [52], [53] \\
\hline
\end{tabular}




\subsection{Road and Traffic factors}

Traffic wheels disturb the surface and avail loose material for entrainment before and during the rainfall [48], [52], [53]. Other road factors include cuts and fills which can divert both surface flow and groundwater regimes; traffic volume, type and frequency which logically define the level of surface disturbance by traffic wheels; road geometry and size which can affect both amount and velocity of water flow at the road surface, and the surface roughness which can decelerate the flow and promote surface infiltration. Road length, geometry, drainage and maintenance activities are argued by $26 \%$, $23 \%, 13 \%, 13 \%$ and $12 \%$ of studies respectively as influential to earth roads erosion (Figure 5). The ruts influence on erosion was reported in $7 \%$ of studies. Table 3 gives trends of erosion (E) due to some factors (F) in terms of increase (I) and decrease (D) generally.

\section{Laboratory experiments}

Erodibility tests were conducted in the civil engineering laboratory of the University of Birmingham, UK. These were performed on six various soils, namely a sand (S) soil mixed with its $0 \%, 5 \%, 10 \%, 15 \%$ and $20 \%$ china clay (CC). The sixth soil was a subbase material. Soils were compacted at maximum dry densities to simulate suitable densities in earth road construction. Moreover, unsoaked CBR tests were carried out immediately after compaction, and after one, five, ten and fifteen days to investigate the impact of clay content on the load bearing capacity. For sand - china clay mixes, CBR increased with increasing China clay content and with increase in time after compaction as in Figure 8. Subbase CBR values were $21.1 \%, 36.5 \%, 62.3 \%, 74.2$ and $77 \%$ respectively after compaction and after one, five, ten and fifteen days. CBR immediately after compaction and after fifteen days are shown in Table 4.

Two slopes, $0 \%$ and $6 \%$ were chosen according to Petts et al. [68] who recommends slopes not greater than $6 \%$ for earth road. A soil testing box of dimensions $0.6 \mathrm{~m}$ $\mathrm{x} 0.3 \mathrm{~m} \times 0.17 \mathrm{~m}$ length, width and height respectively was deemed suitable [69]. Erodibility tests were carried out using a $30 \mathrm{~mm} / \mathrm{hr}$ simulated rainfall for 30 minutes. Ngezahayo et al. [70] provides details on both the design of the rainfall simulator and the soil testing box.

Table 4. Properties of tested soils.

\begin{tabular}{|c|c|c|c|c|c|c|}
\hline Properties & $\mathrm{S}+0 \% \mathrm{CC}$ & $\mathrm{S}+5 \% \mathrm{CC}$ & $\mathrm{S}+10 \% \mathrm{CC}$ & $\mathrm{S}+15 \% \mathrm{CC}$ & $\mathrm{S}+20 \% \mathrm{CC}$ & Subbase \\
\hline Clay (\%) & 0 & 5 & 10 & 15 & 20 & 2 \\
\hline Silt (\%) & 3 & 3 & 3 & 3 & 3 & 5 \\
\hline Sand (\%) & 87 & 84 & 80 & 74 & 72 & 15 \\
\hline Gravel (\%) & 10 & 8 & 7 & 6 & 5 & 78 \\
\hline PI (\%) & 0 & 4.2 & 6.8 & 9.4 & 12.2 & 0 \\
\hline $\mathrm{D} 50(\mathrm{~mm})$ & 0.54 & 0.42 & 0.46 & 0.48 & 0.49 & 6 \\
\hline OMC (\%) & 10.5 & 10.3 & 9.6 & 8.9 & 9.4 & 8.8 \\
\hline $\operatorname{MDD}\left(\mathrm{Mg} / \mathrm{m}^{3}\right)$ & 1.82 & 1.94 & 1.95 & 2.03 & 2.1 & 2.19 \\
\hline CBR after compaction (\%) & 0.47 & 3.1 & 4.3 & 6.1 & 6.5 & 21.1 \\
\hline CBR after 15 days (\%) & 1.1 & 9.8 & 17.6 & 19.8 & 22.5 & 77 \\
\hline OC $(\%)$ & 0.4 & 0.9 & 1.3 & 1.5 & 2.3 & 3.5 \\
\hline $\mathrm{k}(\mathrm{cm} / \mathrm{s})$ & $2.62^{*} 10^{-2}$ & $2.1 * 10^{-3}$ & $3.06 * 10^{-4}$ & $2.29 * 10^{-4}$ & $1.55^{*} 10^{-4}$ & $6.5 * 10^{-2}$ \\
\hline
\end{tabular}

Sediments from erodibility tests were collected every five minutes and oven dried before being weighed up and sieved for particle size distribution analysis. Major findings are that erodibility reduced with clay content increase in $(\mathrm{S}+\mathrm{CC}) \mathrm{mix}$ soils and with slope reduction. The first 5 minutes of the rainfall were characterised by particle detachment, followed by surface saturation and runoff formation. The maximum sediment was collected between 5 and 15 minutes of the rainfall, suggesting that most particles (silt and fine sand) are detached and washed within the first 15 minutes of the rainfall in earth roads. The first 5 minutes 
were of higher infiltration rate for soils with less clay content (S+0\%CC and S+5\%CC), therefore less erosion was observed. The bigger particle size resisted detachment from rain drops, thus the subbase soil was less erodible when compared to $(\mathrm{S}+\mathrm{CC})$ soils.

Among the findings, the particle size distribution curves [70] showed that the soil particle size in the sediment gradually increased with increase in the rainfall duration. The sediment collected after the first five minutes of rainfall contained more fine soils (clay and silt) than the sediment collected after 10 minutes of rainfall. This rule of erosion was respected until the last sediment collected after 30 minutes of rainfall which was mainly of granular soil particles (mainly medium and coarse sand). It was also obvious from the reduction in the cloudiness of the runoff as the rainfall duration increased to indicate that generally fine materials eroded before more granular soil particles.

Results are plotted in the Figures 9, 10 and 11 for the tests done on slope $=6 \%$, and in the Figures 12,13 and 14 for the tests done on the slope $=0 \%$. Respectively, results are for sediment quantities collected at every five minutes intervals; cumulative sediment quantity and cumulative erosion rate for the 30 minutes erodibility tests under simulated rainfall intensity of $30 \mathrm{~mm} / \mathrm{hr}$. The minimum quantities of sediment were collected after the first 5 minutes of rainfall due to raindrops having to detach particles, infiltrate the surface, saturate the surface and then create surface flow. The next 10 to 15 minutes were of higher runoff and most detached particles would be transported during this period after which sediment transport decreased gradually.

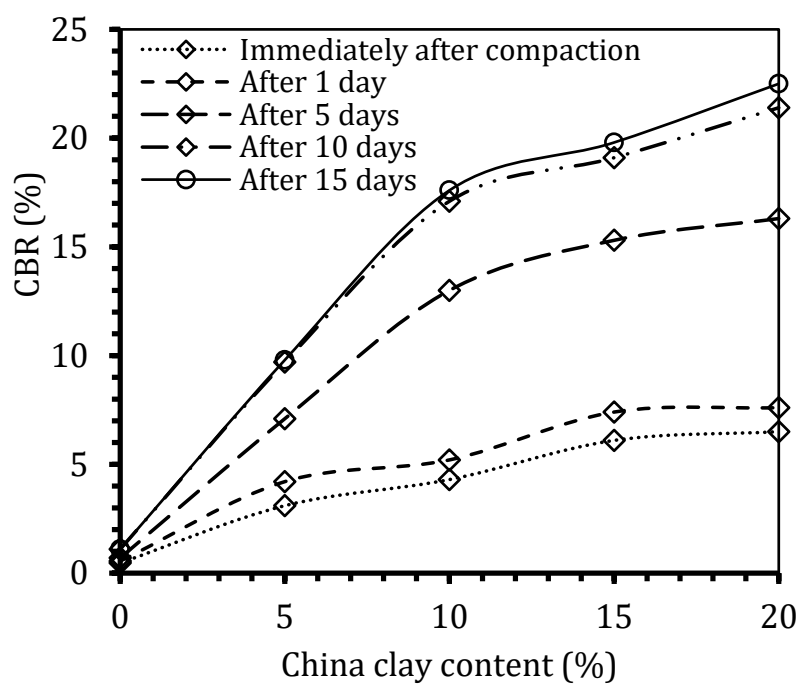

Figure 8. CBR increases with both increase of china clay content and time after compaction.
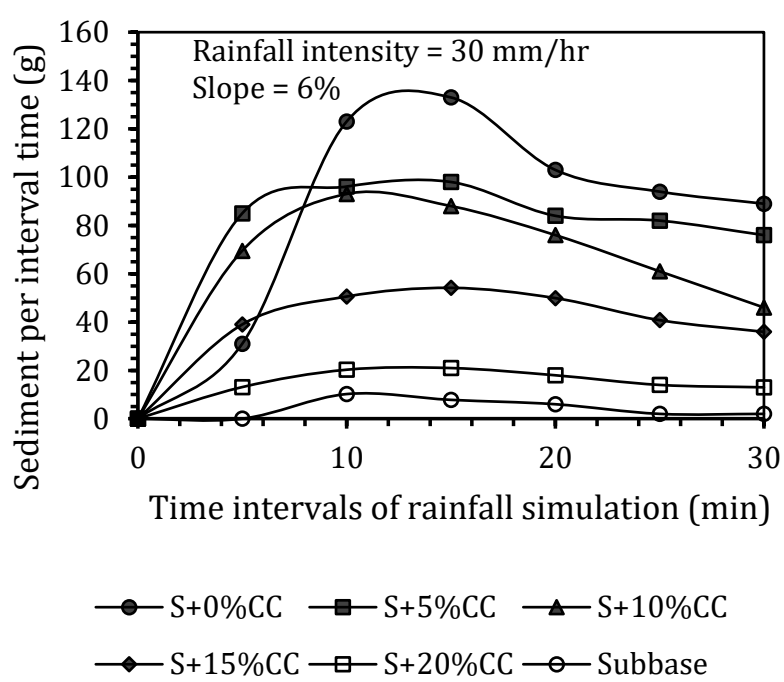

Figure 9. Sediment at rainfall interval times.

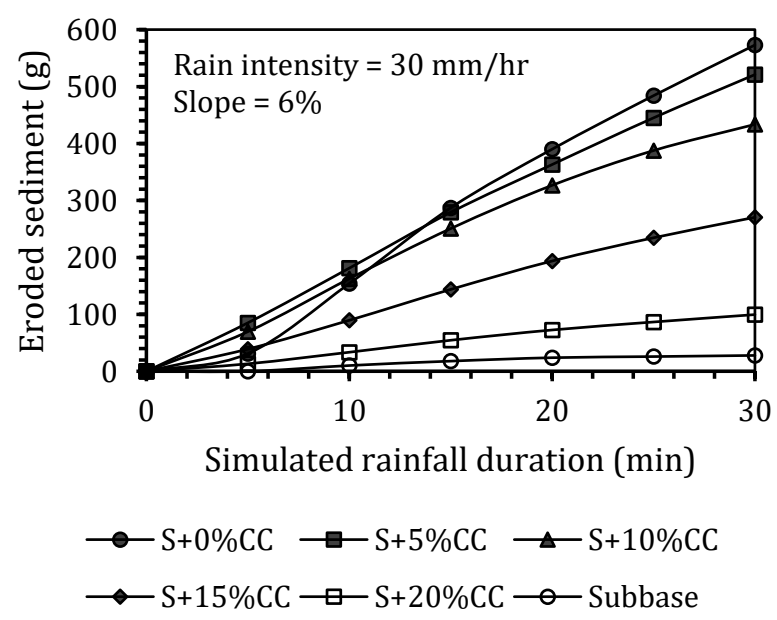

Figure 10. Cumulative sediment with rainfall time.

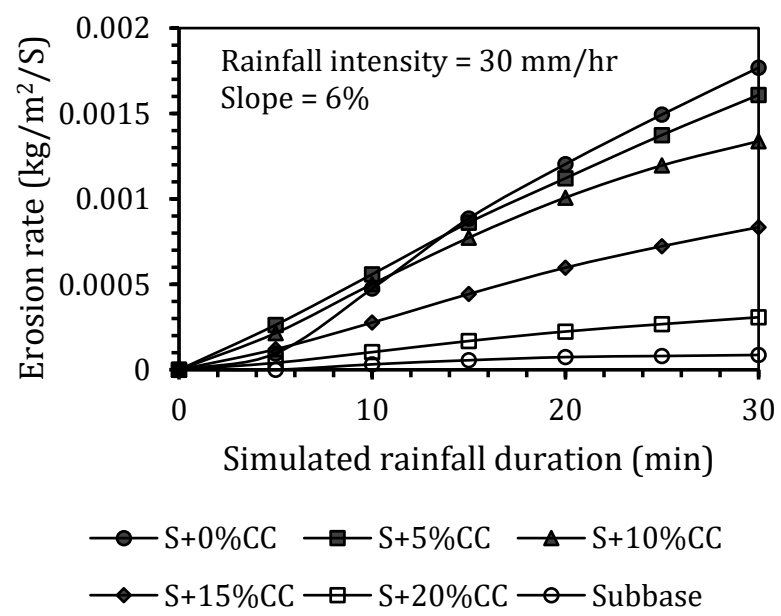

Figure 11. Erosion rate with rainfall time. 


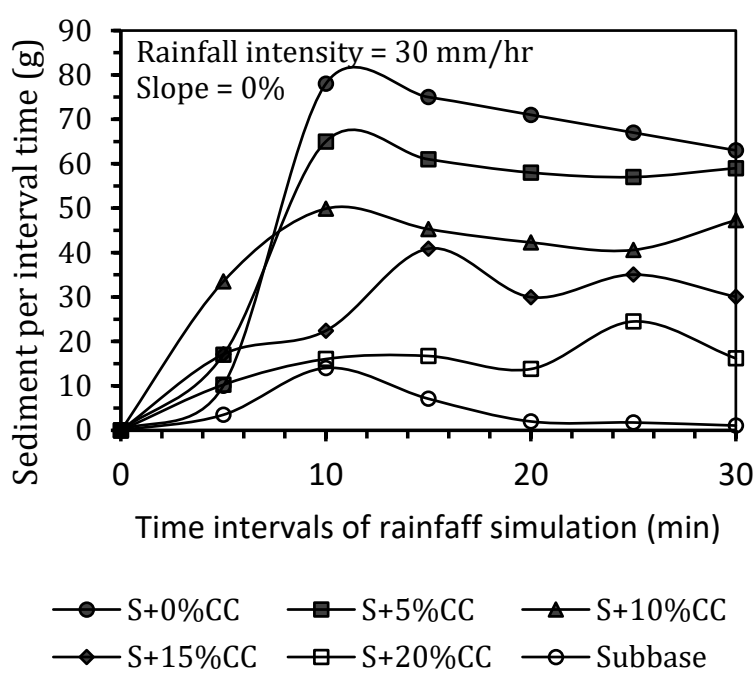

Figure 12. Sediment at rainfall interval times.

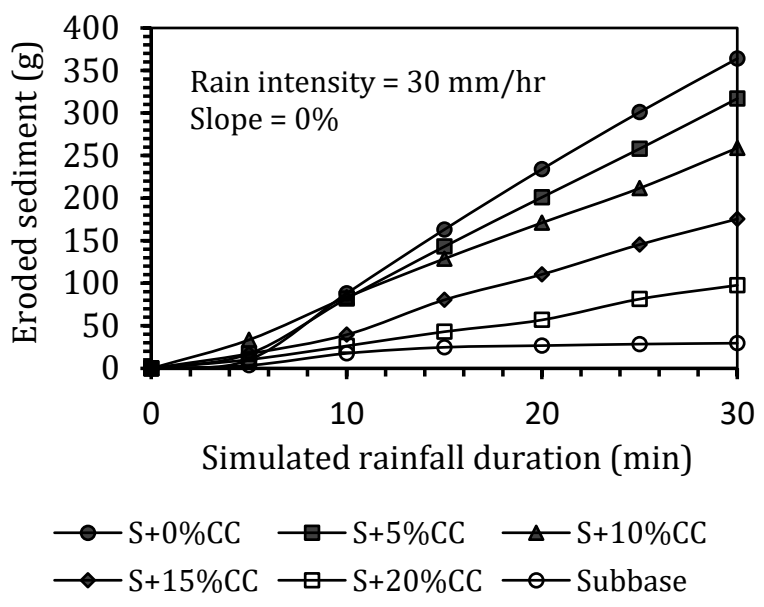

Figure 13. Cumulative sediment with rainfall time.

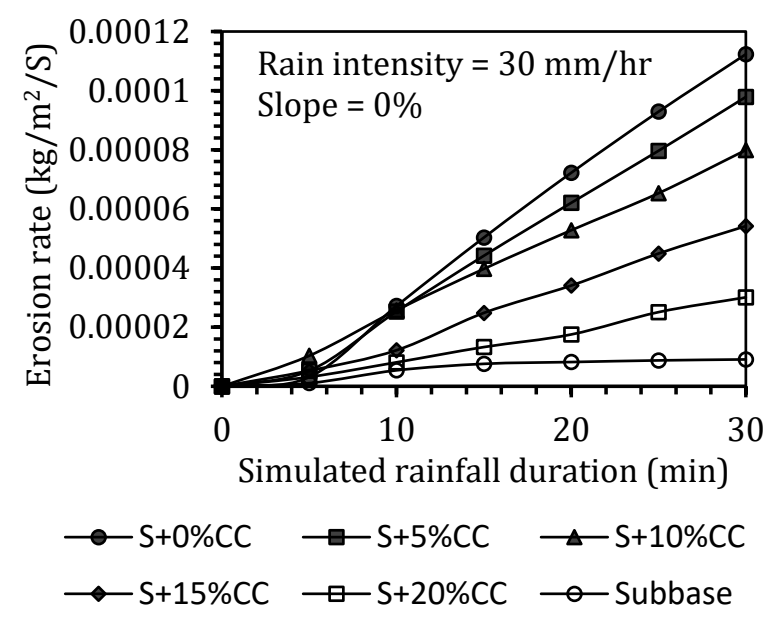

Figure 14. Erosion rate with rainfall time.

\section{Implication for earth roads}

Even though a detailed analysis of published data is reported elsewhere, the findings in this paper show that soils used at the surface of earth roads need very careful consideration as they are most affected by both the climate (temperatures, rainfall) and traffic loadings. The latter impose shear stresses that can dislodge surface particles, which when exposed to dry conditions may be eroded by natural wind or that generated by moving vehicles. If the dislodged soils are exposed to rainwater, they may be transported due to splashing, or surface water flow. Also, inundated surface soils may be dislodged due to traffic wheel-soil interaction. Therefore, in addition to the ability of soils to support traffic loadings and traffic speed as key design factors, designs need also to consider soil-wheel interactions. Since it is not possible to control rain intensity and duration, it is possible to engineer road design to minimise the loss of soils due to erosion. In addition, these designs need to pay particular attention to drainage, surface slopes and degree of compaction. In some cases, regardless of the level of compactions soils will remain highly susceptible to erosion. In such instances, particle size of soil may need to be modified to ensure that the road is constructed using well graded interlocking granular soils that achieve high compaction levels. Also, the amount of clay content in the uppermost surface layer must be controlled to have the plasticity index of about 10\% [67], [71] as such soil will resist detachment due to rainfall by both improved surface cohesion and high level of compaction. Where such soils cannot be available, some form of soil stabilisation techniques may need to be used.

\section{Conclusion}

Bulk of the 71 studies found that interrill and rill erosion were the most prominent types of erosion that cause most of earth road failures. Judging by both the number of studies and the laboratory experiments results, the five most important factors that affect erosion in those roads were particle size distribution of the soil, slope, amount of rainfall, rainfall intensity and duration of rainfall. Further, the literature showed that soils with higher plasticity needed higher critical shear stresses to initiate erosion in those soils. This agrees with laboratory results which showed less erosion for soils with more clay content, thus higher plasticity. Those soils resisted both the raindrops kinetic energy which detaches particles and the subsequent flow shear stresses better than soils with less clay content and 
lower plasticity. Low plasticity soils, comprising silts and fine sands, are likely to erode. Dislodgement of particles due to rain drops shows that silts and fine sands are likely to be easily dislodged by both drops kinetic energy and surface flow stresses. Larger and finer soils particles need higher energy to be dislodged and it could be due to the robustness of particles and cohesion forces respectively.

\section{Acknowledgements}

The Commonwealth Scholarship Commission in the UK are acknowledged for financial support. The authors would like to thank the reviewers for their thoughtful comments and efforts towards improving the manuscript.

\section{References}

[1] World Bank, "Safe, Clean and Affordable Transport for Development," WB Group's Transport Business Strategy, 2008.

[2] M. P. N. Burrow, H. Evdorides, G. S. Ghataora, R. Petts and M.S. Snaith, "The evidence for rural road technology in low-income countries," in Proceedings of the ICE, London, 2016, vol. 169, TR6, pp. 366-377.

[3] A. Faiz, "The Promises of Rural Roads. Review of the Role of Low-Volume Roads in Rural Connectivity, Poverty Reduction, Crisis Management and Livability," TRB Low Volume Roads Committee, Circular E-C 167, 2012.

[4] J. Riverson, J. Gaviria and S. Thriscutt, "Rural Roads in Sub-Sahara Africa: Lessons from World Bank Experience," Technical Paper, no. WTP 141, Washington DC, World Bank, 1991.

[5] J. Cook, R. Petts, C. Visser and A. Yiu, "The Contribution of Rural Transport to Achieve Sustainable Development Goals," Research Community for Access Partnership \& Partnerships on Sustainable, Low Carbon Transport, 2017.

[6] World Factbook, "Field listing: Roadways" [Online]. Available:

https://www.cia.gov/library/publications/theworld-factbook/fields/2085.html, 2017.

[7] S. Leguédois and Y. Le Bissonnais, "Size Fractions Resulting from an Aggregate Stability Test, Interill Detachmnt and Transport," J. E. Surface Processes and Landforms, vol. 29, pp. 1117-1129, 2004.

[8] R. P. C. Morgan, "Field Studies of Rainsplash Erosion," J. Earth Surface Processes, vol. 3, pp. 295-299, 1978.
[9] P. I. A. Kinnell, "Raindrop-impact-induced erosion processes and prediction: review," J. Hyd. P., vol. 19, p. 2815-2844, 2005.

[10] K. Nanko, S. Mizugaki, Y. Onda, "Estimation of soil splash detachment rates on the forest floor of an unmanaged Japan cypress plantation based on field measurements of through fall drop sizes and velocities," Cat., vol. 72, p. 348-361, 2008.

[11] R. P. C. Morgan, D. D. V. Morgan and H. J. Finney, "A Predictive Model for the Assessment of Soil Erosion Risk," JAER, vol. 30, pp. 245-253, 1984.

[12] R. B. Bryan, "Soil erodibility and processes of water erosion on hillslope," J. Geomorphol., vol. 32, pp. 385-415, 2000.

[13] J. Poesen and J. Savat, "Detachment and Transport of Loose Sediment by Raindrop Splash. Part 2: Detachability and Transportability Measurements," Catena, vol. 8, pp. 19-41, 1981.

[14] J. Savat and J. Poesen, "Detachment and Transportation of Loose Sediment by Raindrop Splash, Part 1: The Calculation of Absolute Data on Detachability and Transportability," Catena, vol. 8, pp. 1-17, 1981.

[15] R. P. C. Morgan, J. N. Quinton, R. E. Smith, G. Govers, J. W. A. Poesen, K. Auerswald, G. Chisci, D. Torri, M. E. Styczen and A. J. V. Folly, "The European soil erosion model: documentation and user guide," Cranfield University, 1998.

[16] J. D. Pelletier, "Fluvial and slope-wash erosion of soil-mantled landscapes: detachment or transport limited?" ESPL, 2011.

[17] K. H. Alfsen, M. A. De Franco, S. Glomsrød and J. Torgeir, "The cost of soil erosion in Nicaragua," J. Ecological Economics, vol. 16, pp. 129-145, 1996.

[18] M. Ali and G. Sterk, "Availability and performance of sediment detachment and transport functions for overland flow conditions," J. Hydrol. Sciences, vol. 60, no. 9, pp. 1550-1565, 2015.

[19] C. Salles, J. Poesen and G. Govers, "Statistical and physical analysis of soil detachment by raindrop impact: Rain erosivity indices and threshold energy," J. Water Resources Research, vol. 36, no. 9, pp. 2721-2729, 2000.

[20] B. Wang, G. H. Zhang, Y. Y. Shi, X. C. Zhang, "Soil detachment by overland flow under different vegetation restoration models in the Loess Plateau of China," Catena, vol. 116, pp. 51 - 59, 2014.

[21] S. Yariv, "Comments on the Mechanism of Soil Detachment by Rainfall," J. Geoderma, vol. 15, pp. 393-399, 1976. 
[22] J. Boardman and D. A. Robinson, "Soil erosion, climatic vagary and agricultural change on the Downs around Lewes and Brighton, autumn 1982," J. App. Geography, vol. 5, pp. 243-258, 1985.

[23] B. Barthès and E. Roose, "Aggregate stability as an indicator of soil susceptibility to runoff and erosion; validation at several levels," Catena, vol. 47, pp. 133-149, 2002.

[24] M. A. Nearing, G. N. Foster, L. J. Lane and S. C. Finkner, "A Process - Based Soil Erosion Model for USDA-Water Erosion Prediction Project Technology," Trans. ASAE, vol. 32, no. 5, pp. 15871593, 1989.

[25] T. A. Cochrane and D. C. Flanagan, "Detachment in a Simulated Rill," ASAE, vol. 40, no. 1, pp. 111-119, 1996.

[26] Minnesota Local Road Research Board, "Erosion Control Handbook for Local Roads," 2003.

[27] P. G. Jungerius, J. Matundura and J. A. M. Van de Ancker, "Road Construction and Gully Erosion in West Pokot, Kenya," J. Earth Surface Proc and Landforms, vol. 27, pp. 1237-1247, 2002.

[28] G. I. Nwankwor, U. P. Udoka, B. C. Egboka and A. I. Opara, "The Mechanics of Civil -Works Induced Gully Erosion: Applications to Development of Preventive Measures in South Eastern Nigeria," J.A.E.E.S., vol. 3, no. 2, pp. 60-65, 2015.

[29] W. P. Carey and A. Simon, "Physical basis and potential estimation techniques for soil erosion parameters in the Precipitation-Runoff Modelling System (PRMS)," U.S. Geological Survey, W R Investigations Report 84 - 42 18, 1984.

[30] L. T. Zhang, Z. L. Gao, Z.B. Li and H. W. Tian, "Downslope runoff and erosion response of typical engineered landform to variable inflow rate patterns from upslope," J. Natural Hazards, vol. 80, pp. 775-796, 2016.

[31] A. Knapen, J. Poesen, G. Govers, G. Gyssels and J. Nachtergaele, "Resistance of soils to concentrated flow erosion: A review," J. Earth-Science Reviews, vol. 80, pp. 75-109, 2007.

[32] I. Haghighi, C. Chevalier, M. Duc, S. Guédon and P. Reiffsteck, "Improvement of Hole Erosion Test and Results on Reference Soils," J. Geotech and Geoenvir Eng., vol.139, no. 2, pp. 330-339, 2013.

[33] J. M. Reichert, M. J. Schafer, E. A. Cassol and L. D. Norton, "Interrill and rill erosion on a tropical sandy loam soil affected by tillage and consolidation," 10th Int. Soil Cons. Org. Meeting, PU and USDA-ARS- NSE. Lab., May 24-29, 1999, 2001.
[34] H. B. Nagaraj, B. Reesha, M. V. Sravan and M. R. Suresh, "Correlation of compaction characteristics of natural soils with modified plastic limit" J. Transport. Geotechnics, vol. 2, pp. 65-77, 2015.

[35] M. A. Nearing, J. M. Bradford and S. C. Parker, "Soil Detachment by Shallow Flow at Low Slopes," Soil Sc. Society American J., vol. 55, pp. 339-344, 1991.

[36] G. H. Zhang, G. B. Liu, K. M Tang, X. C. Zhang, "Flow Detachment of Soils under Different Land Uses in the Loess Plateau of China," J. Trans. ASABE, vol. 51, no. 3, pp. 883-890, 2008.

[37] Z. W. Li, G. H. Zhang, R. Geng and H. Wang, "Rill erodibility as influenced by soil and land use in a small watershed of the Loess Plateau, China," J. Biosystems Eng., vol. 129, pp. 248-257, 2015.

[38] J. Poesen, J. Nachtergaele, G. Verstraeten and C. Valentin, "Gully erosion and environmental change: importance and research needs," Catena, vol. 50, pp. 91-133, 2003.

[39] G. T. Tengbeh, "Effect of Grass Roots on Shear Strength Variations with Moisture," J. Soil Tec., vol. 6, pp. 287-295, 1993.

[40] V. Chowdary, G. Ramulu, S. Shankar and C. S. R. K. Prasad, "Influence of unbound material properties on rutting potential of low volume roads," J. Elixir Cem. Concrete Comp., vol. 42, pp. 6377-6382, 2012.

[41] K. V. Dubé, W. F. Megahan, M. McCalmon, "Washington Road Surface Erosion Model," Washington State: DNR, 2004.

[42] L. Cao, K. Zhang, H. Dai and Y. Liang, "Modelling Interill Erosion on Unpaved Roads in the Loess Plateau of China," J. Land. Degrad. Develop., 2013.

[43] J. Arnaez, T. Lasanta, P. Ruiz-Flaño and L. Ortigosa, "Factors affecting runoff and erosion under simulated rainfall in Mediterranean vineyards," $J$. Soil and Tillage Res., vol. 93, pp. 324-334, 2007.

[44] R. B. Foltz and E. R. Burroughs, "Sediment production from forest roads with wheel ruts," In Proc. Watershed Plan. \& Analysis in Action, Durango, CO, July 9-11, 1990, ASCE: Reston, VA pp. 266-275.

[45] G. Liu, F. X. Tian, D. N. Warrington, S. Q. Zheng and Q. Zhang, "Efficacy of Grass for Mitigating Runoff and Erosion from an Artificial Loessial Earthen Road," J. Trans. ASABE, vol. 53, no. 1, pp. 119-125, 2010.

[46] R. B. Foltz, H. Rhee and W. J. Elliot, "Modeling changes in rill erodibility and critical shear stress on native surface roads," J. Hydrological Processes, vol. 22, pp. 4783-4788, 2008. 
[47] M. E. Obi and F. K. Salako, "Rainfall parameters influencing erosivity in Southeastern Nigeria," Catena, vol. 24, pp. 275-287, 1995.

[48] L. Cao, K. Zhang and W. Zhang, "Detachment of road surface soil by flowing water," Cat., vol. 76, pp. 155162, 2009.

[49] G. H. Zhang, B. Y. Liu, M. A. Nearing, C. H. Huang and K. L. Zhang, "Soil Detachment by Shallow Flow," J. Trans. ASAE, vol. 45, no. 1, pp. 1-8, 2001.

[50] M. A. Nearing, J. R. Simanton, L. D. Norton, S. G. Bulyigin and J. Stone, "Surface Erosion by Surface Water Flow on a Stony Semi- Arid Hillslope," J. Earth Sur. Proc. Landf., vol. 24, pp. 677-684, 1999.

[51] L. T. Zhang, Z. L. Gao, S. W. Yang, Y. H. Li and H. W. Tian, "Dynamic processes of soil erosion by runoff on engineered landforms derived from expressway construction: A case study of typical steep spoil heap," Cat., vol. 128, pp. 108-121, 2015.

[52] R. M. Iverson, "Processes of Accelerated Pluvial Erosion on Desert Hillslopes Modified by Vehicular Traffic," J. Ear. Sur. Proc., vol. 5, pp. 369-388, 1980.

[53] A. D. Ziegler, T. W. Giambelluca, M. A. Nullet, R. A. Sutherland, S. Yarnasarn, J. Pinthong, P. Preechapanya and S. Jaiaree, Toward understanding the cumulative impacts of roads in upland agricultural watersheds northern Thailand, J. Ag. Ec. Env., vol. 104, pp. 145-158, 2004.

[54] P. Paige-Green, "Strength and Behavior of Materials for Low-Volume Roads as Affected by Moisture and Density," J.T.R.R., vol. 1819, no. 2, pp. 104-109, 2003.

[55] F. Brunori, M.C Penzo and D.T Firenze, Soil Shear Strength: Its Measurement and Soil Detachment, Catena, vol. 16, pp. 59-71, 1989.

[56] G. J. Hanson and S. L. Hunt, "Lessons Learned Using Laboratory Jet Method to Measure Soil Erodibility of Compacted Soils," J. Applied Eng. Agriculture, vol. 23, no. 3, pp. 305-312, 2007.

[57] J. L. Briaud, "Case Histories in Soil and Rock Erosion: Woodrow Wilson Bridge, Brazos RiverMeander, Normandy Cliffs, and New Orleans Levees," The 9th Ralph B. Peck Lecture, Reston, Virginia, J.G.G.E., vol. 134, no. 10, pp. 1-27, 2008.

[58] E. I. Ekwue, "The Effects of Soil Organic Matter Content, Rainfall Duration and Aggregate Size on Soil Detachment," J. Soil Technology, vol. 4, pp. 197207, 1991.
[59] D. Torri and J. Poesen, "The Effect of Soil Surface Slope on Raindrop Detachment," Cat., vol. 19, pp. 561-578, 1992.

[60] K. Behak, "Performance of Full-Scale Test Section of Low-Volume Road with Reinforcing Base Layer of Soil-Lime" J. T. R. B., vol. 2204, pp. 158-164, 2011.

[61] R. S. B. Greene and P. B. Hairsine, "Elementary Processes of Soil - Water Interaction and Thresholds in Soil Surface Dynamics: A Review," J. E. Sur. Proc. Landf., vol. 29, pp. 1077-1091, 2004.

[62] C. E. Ramos-Scharrón and L. H. MacDonald, "Measurement and Prediction of Sediment Production from Unpaved Roads," J. Earth Surface Proc. Landforms, vol. 30, pp. 1283-1304, 2005.

[63] S. S. Kukal, H. S. Sur and S. S. Gil, "Factors responsible for soil erosion hazard in submontane Punjab, India," J. Soil Use Mgt., vol. 7, no. 1, pp. 38-44, 1991.

[64] D. Favis-Mortlock and J. Boardman, "Nonlinear responses of soil erosion to climate change: a modelling study on the UK South Downs," Catena, vol. 25, pp. 365-387, 1995.

[65] R. H. Jones, "Frost heave of roads," Quarterly J. Eng. Geology, vol. 13, pp. 77-86, 1980.

[66] R. Van Klavern, K. McCool, "Freeze-Thaw, Water Tension Effects on Soil Detachment," Soil Sc. Soc. American J., vol.74, pp.1327-1338, 2010.

[67] P. Paige-Green, "Dispersive and erodible soils fundamental differences," Problem soils in SA conference, 2008, Midrand, Gauteng, November 3rd - 4th Pretoria, CSIR Built Envir., pp. 59-65.

[68] R. Petts, J. Cook, P.G. Tuan, B.T. Dzung and H. Kackada, "Rural Road Surfacing Research for Sustainable Access and Poverty Reduction in South East Asia", Indian Roads Congress, Int. Seminar on Innovations in Constr. \& Maint. of Flexible Pavements to be held at Agra from 1-4 Sept. 2006.

[69] A. Knapen, J. Poesen, G. Govers, G. Gyssels and J. Nachtergaele. Resistance of soils to concentrated flow erosion: A review. Earth Sc. Rev., 80: 75 - 109, 2007.

[70] E. Ngezahayo, M. P. N. Burrow and G. S. Ghataora, Rainfall Induced Erosion of Soils Used in Earth Roads, Proc. $7^{\text {th }}$ Intern. Symposium on Deformation Characteristics of Geomaterials, IS- Glasgow, UK, $26^{\text {th }}-28^{\text {th }}$ June, E3S Web of Conf. 92: 17006, 2019, https://doi.org/10.1051/e3sconf/20199217006.

[71] G. Keller and J. Sherar (2003). Low-Volume Roads Engineering. Best Management Practices Field Guide. US Agency for International Development. 